\title{
DEUT 23:18 AND THE LITERAL AND METAPHORICAL ASPECTS OF THE HIRE OF A HARLOT
}

\author{
Blessing Onoriode Boloje ${ }^{1}$ \\ University of Pretoria
}

\begin{abstract}
The language of prostitution is used in the Hebrew Bible/Old Testament in both literal and metaphorical senses. Although harlots (prostitutes) and prostitution are mentioned in the HB/OT (Lev 18; 21:1-15 and Deut 23), these harlots are not punished like people who are caught in the act of adultery. The specific reference that is hinted at in Deut 23:18 and the question pertaining to the nature of the activity denounced by Yahweh in the text has generated speculation and requires some study. This article systematises the possibilities, literally and metaphorically - evaluating prostitution as foreign, religiously deviant or morally detestable. The critical concern of this article is what, according to Deut 23:18, God hates: harlots, the practice of prostitution or the use of the wages (gifts) thereoffor the redemption of vows; and what these imply. In this article, the clear pairing in the

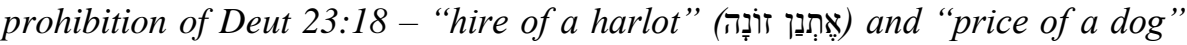

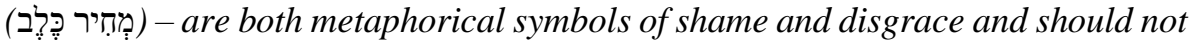
be accepted for fulfilling religious vows.
\end{abstract}

Key words: Hire of a harlot; Prostitution; Deut 23:18; Shame and disgrace; Literal and metaphorical; Religious vows

\section{Introduction}

In the Hebrew Bible/Old Testament, the language regarding prostitution is used in both literal and metaphorical senses. Harlots (prostitutes) and prostitution are mentioned in the HB/OT in Lev 18 and 21:1-15 and Deut 23 but these harlots are not punished like people who are caught in the act of adultery. Israel's moral code stipulated that a woman's sexuality belonged exclusively to her husband, for whom it was reserved both before and after marriage. In the HB/OT, the most serious sexual offence, namely violation of a husband's sexual rights, is denoted as adultery. All other instances of sexual intercourse outside marriage are designated as fornication or prostitution (see Deut 22:13-21; Lev 21:9; cf. Gen 34:31) (Bird 2006:42). It is widely imagined and held that in ancient Israelite society harlots or prostitutes belonged to the symbolically expendable class of people who were economically dependent. According to Mercedes L. García Bachmann (2013:1), this phenomenon is not new: "The biblical record is filled with 'expendables,' people who are economically dependent and thus bound to work for others and/or depend on others' good-will." These categories of persons include

1 Blessing Onoriode Boloje is a Research Fellow of the Alexander von Humboldt Foundation, Ruhr-Universität Bochum, Germany; and Research Associate, Department of Old Testament and Hebrew Scriptures, Faculty of Theology and Religion, University of Pretoria, South Africa. Email: pstbobson@yahoo.co.uk ORCID ID: https://orcid.org/0000-0002-7480-3805 
indentured Israelites, foreign slaves, artisans, daily wage workers, prostitutes, widows and orphans too helpless to fend for themselves (Bachmann 2013:1).

The situation is complicated by the cultures of antiquities that reflected and understood the hierarchy of honour at different levels. Hierarchy ideas usually correspond to the real economic, social, political and religious levels in society. Therefore, ancient culture and society legitimised their existing structures and supports with such a common hierarchy of honour (Dietrich 2012:16). Within the context of the ancient Mediterranean world, life revolved around the core social values of honour and shame. Honour is usually considered as the bedrock of position and reputation in society. It places worth on someone according to how the person is seen by others and is thus a reflection of the power and influence that person wields in society (Simkins 1994:49; Simkins 2005:104-106; Bergant 1994:33). Susan A. Brayford argues that,

\begin{abstract}
Although honor is almost always an important criterion in assessing the male characters, shame, in its positive sense, is not always a major factor in female characterization. Pentateuchal texts, in particular, do not represent consistently the value accorded to positive female shame in the Mediterranean [the cultural milieu that most closely corresponds with the values of the dominant Hellenistic culture in the later centuries B.C.E. and early centuries C.E.] model of the honor/shame code. (Susan A. Brayford 1999:164).
\end{abstract}

Dominant cultural orientation, especially as reflected in Pentateuchal accounts, Deuteronomistic History (Gen 34; 1 Sam 31; 2 Sam 13) and other biblical writings (cf. Stansell 1994:55-79; Stone 1995:87-107; Matthew 1998:97-112), easily ascribe shame and dishonour to this class of people. However, they highly esteem those who attend to cultic/ritual requirements and other religious directives and regulations (those in good moral standing with Yahweh) and related upstanding families, those who possess symbolic material assets like land, those in high leadership positions, and women who maintain sexual purity and privacy and avoid male counterparts except family members (Bachmann 2013:3). As a direct contrast to honour, shame is a social misfortune, especially shame associated with the negative aspects of life. However, the sexual decorum and social decency of women is an aspect of shame that is understood to be a cherished virtue and thus considered positive (Brayford 1999:163-165). Against this background of what constitutes honour and shame, this article examines the literal and metaphorical aspects of the prohibition of the hire (wages, earnings) of a harlot in Deut 23:18. It attempts to establish the lexical literal meaning of the text, examine contextual arguments and consequently conclude with some metaphorical implications. The critical concern of this article is what, according to Deut 23:18, God hates: harlots, the practice of prostitution or the use of the wages (gifts) thereof for the redemption of vows; and what these imply?

\title{
Lexical and literal aspects of Deut 23:18: Hire of a harlot and price of a dog
}

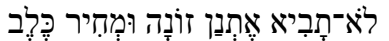

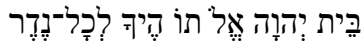

MT

23:19
You shall not bring the hire of a harlot or the wages of a dog into the house of the LORD your God for any votive
NASB

$23: 18$ 


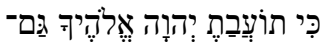

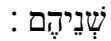

offering, for both of these are an

abomination to the LORD your God.

The Hebrew feminine noun זוֹנָה (translated as harlot or prostitute) is used for someone who practices prostitution either occasionally or professionally $(1 \mathrm{Kgs} 3: 16 \mathrm{cf}$. Gen 34:31) usually for financial rewards (Frymer-Kensky 1992:59). The verbal form זָָָ (act the harlot, commit fornication, be a prostitute) is used in both literal and metaphorical senses. In its literal form, the word carries the basic idea of participating in illicit heterosexual intercourse - especially by women. ${ }^{2}$ As a general term for non-marital illicit heterosexual intercourse, the verb זָָָ is normally used only with a female subject, since it is only for women that marriage is the primary determinant of legal status and obligation (Bird 2006:42). The participial form (זֹזָנָ) is mostly used to describe the harlot

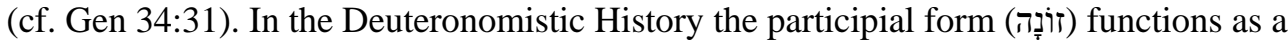

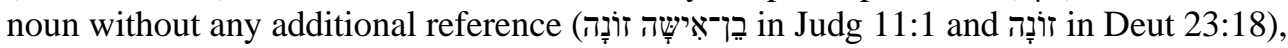
is used once with and without the article (הָינוֹ in I Kgs 22:38 and 16:1), and appears twice with the proper noun, Rahab (Josh 2:1; 6:17-25) (Bachmann 2013:292). Such persons received hire or wages (Deut 23:18), had marks of identification (Gen 38:15; Prov 7:10; Jer 3:3), had homes (Jer 5:7), and were to be avoided (Prov 23:27) (Wood 1980:563).

Metaphorically, the idea may imply a prohibition on deliberate sexual intercourse of a nation (mostly Israel) having relations with foreign nations. It may also refer to religious intercourse, of Israel worshipping gods other than Yahweh. Accordingly, the condemnations and prescribed punishments found in the Hebrew Bible certainly refer to figurative uses of זٓ⿱一𫝀㇈ in connection with offences of covenant violation and/or the sin of apostasy (Bird 2006:42). Priestly legislation specifies prostitution as profane and thus prohibits priests from marrying a זٓנָנה (prostitute) (Lev 21:7, cf. 21:9; Amos 7:17). In the Wisdom literature, ז זוֹנָה is a recognisable figure of urban life in a number of proverbs, similes, and narratives with which men are counselled to avoid the attractions of women. In Prov 6:26 the cost of adultery is compared with that of a זוֹנָדָ :For on account of one is reduced to a loaf of bread, and an adulteress hunts for the precious life" (NASB). The personification of the city as a prostitute is observed in the well-known "Song of the harlot" (Isa 23:15-16). References to prostitutes as symbols of dishonour are found in the Samson story that depicts his heroic exploits and fall in association with a woman (Judg 16:1-4), the story of Jephthah as a social outcast (Judg 11:1-2), and Joel's description of the value of the prostitute (Joel 4:2-3).

The associated singular noun has a literal animalistic meaning of dog (form of drinking, Judg 7:5; watchdog for herds, Isa 56:10; hunting dog, Ps 22:16; an unclean

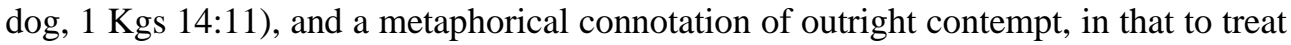
someone like a dog, is to treat them as worthless (1 Sam 17:43). Dogs are aggressively rapacious and are to be feared (Jer 15:3). The barking of a dog is like the uncomplimentary disapproval of an enemy (Ps 59:6). An extension of these metaphorical nuances is that "for one's body to be eaten by dogs was the ultimate tragic end to a life" (Oswalt 1980:981). Deuteronomy may have used (dog) as a colloquialism for a secular male prostitute, projected as an unfavourable epithet (Koehler and Baumgartner

References to men are found in Ex 34:16 and Num 25:1. 
2000:476). Although the female profile of prostitution is well recognised, the phenomenon of male prostitution appears to be minor in ancient Israel. Bird (2006:49) makes these insightful remarks,

The sole reference (if correctly interpreted) is found in a prohibition in Deuteronomy 23:18 [Heb. 23:19] ... It is generally accepted that "dog" in this passage refers to a male prostitute. If this is in fact the case, the order in this genderpaired reference further emphasises the secondary character of the male class; in contrast to the normal male-female order, the term for the female practitioner is the leading and defining term. (Bird 2006:49)

The masculine singular noun wֶתֶּ (wage, gift, hire - especially of a harlot) appears only in connection with זٓ⿱一𫝀㇈ה (harlot), mostly in a metaphorical sense except in Deut 23:18, where it is intended literally. Elsewhere it is used to figuratively describe idolatrous Israel (Hos 9:1), Judah/Jerusalem (Ezek 16:31-41), Tyre (Isa 23:17-18), and the expensively accumulated idols of Samaria (Mic 1:7) (Mays 1976:47; Brown, Driver and Briggs 1997:1072; Dempster 2017:71). ${ }^{3}$

The associated masculine noun pִrice) in the prohibition of Deut 23:18, applies to several situations in the Hebrew Bible. In 2 Chron 1:16 (cf. I Kgs 10:28) it is used to describe the horses imported by Solomon from Egypt (note the specific reference to 600 shekels of silver for a chariot and 150 for a horse). In 2 Sam 24:24, "King David said to

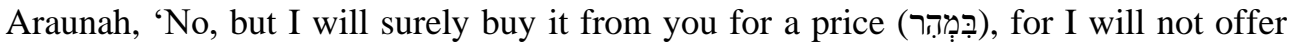
burnt offerings to the LORD my God which cost me nothing.' So David bought the threshing floor and the oxen for fifty shekels of silver" (NASB). It pictures Yahweh giving Israel away for a bargain (Ps 44:13). Isa 55:1 describes the free salvation God offers as not involving money and without מִזִ (price). Job 28:15 announces that wisdom cannot be exchanged for gold, not at any מְזָירָ (price) (cf. Prov 17:16). One of the greatest tragedies in Judah was that her rulers judged for שהחד (reward), her priests taught for a דֶֶֶ (price) and her prophets divined for (money) (Mic 3:11) (Von Rad 1962:244; Allen 1973:28; Mays 1976:89-90; Andersen and Freedman 2000:359; Waltke 2007:168; Nogalski 2011:547). Notwithstanding, Bachmann argues that (ְ̣זיר (price),

... has a literal as well as a theological meaning, and its use is traced through very different texts (prophetic utterances, wisdom sayings, narratives). Both are not exactly parallel terms, since מחיר denotes the price for an item of goods, while אתנן, the wages for a service. (Bachmann 2013:299)

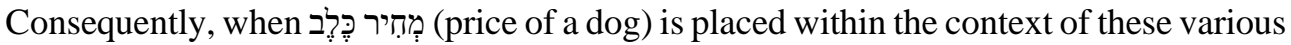
usages, it becomes ironic slang or a metaphor for something of very little value.

Dempster (2017:71) observes that in the book of Micah, "the prophets indicate that the money paid for the services of temple prostitutes and which had been converted to temple furniture and idols will be taken by the military enemy and used to pay prostitutes when the soldiers return to their homeland. Thus the wages of prostitutes will again be used, but this time in an idolatrous land far from Israel." 


\section{Contextual arguments: Between sacred (cultic) and temple prostitution}

Deuteronomy 23 contains directives to the congregation of Israel on various laws: Laws of exclusion from and acceptance into the congregation (vv. 1-8), ${ }^{4}$ purity in the Israelite camp (vv. 9-14; cf. Lev 15:16-18); provision of asylum for foreign slaves who escaped from their masters (vv. 15-16); prohibition on sacred prostitution (vv. 17-18); prohibition on charging interest to the family of Israel (vv. 19-20); the significance of keeping vows (vv. 21-23); and the right to glean given to travellers (vv. 24-25). While these directives lack uniformity, ${ }^{5}$ they reflect interesting perspectives on the social and theological ideals of Yahweh's people (Bachmann 2013:293).

It is significant that Deut 23:16-26 and 24:5 are believed to be a continuation of the social ethos series in Deut 22:1-12, especially of the brotherly ethos of the post-exilic continuation through commandments of purity among the addressees of Deuteronomy. This socio-ethical series is considered to serve as a structural framework for the laws in Deuteronomy, as Otto (2017:1784) notes: "Diese Reihen dienen als Fachwerkstruktur im Aufbau der Gesetze in Dtn 12-25." In his explanation regarding Deut 23:18-19, Otto notes that he believes that these are a post-exilic redaction with a series of stylistic forms. He notes:

In Dtn 23, 18-19 übernimmt die nachexilische Fortschreibung den Griffel mit einer Reihe von Lexemen, die im Deuteronomium Hapax legomena sind, so qedešāh/qādeš, 'cetnan zônāh, mehîr kalab, was Dtn 23, 18-19 als undeuteronomisch zeigt. Insbesondere ist einschlägig, dass das deuteronomische Deuteronomium nicht vom Tempel als bêt JHWH spricht, sondern als dem von JHWH erwählten Ort. Dtn 23, 18-19 hat seine nächste Parallele in dem Verbot in Lev 19, 29, die Tochter nicht durch Hurerei zu entweihen ('al tehallel'cet bittekā lehaznôtā). (Otto 2017:1785).

Scholarly discussions regarding Deut 23:17-18 (Deut 23:18-19 MT) revolve around the theological employment of the language of prostitution; history of interpretation identifies prostitution with pagan religious practices, especially of "Canaanite" and ancient "oriental" religions. The broad metaphorical use of the verb זָ has generated perplexity, especially in secondary literature. This is complicated further by passages that juxtapose זָָ with a term for a religious or cultic devotee (Gen 38:12-30 esp. 15,

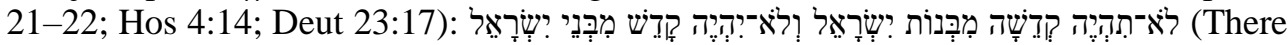
shall be no pִ pult prostitute among the daughters of Israel and none of the sons of Israel shall be a 2000:1075). ${ }^{6}$ The term ${ }^{2}$ ? characteristics of which elude interpreters, and which lacks comprehensive explanations. The Hebrew tri-radicals $\boldsymbol{w}-\mathbf{T}$-P (and in most Semitic languages) usually refer to something that is "consecrated" "set apart" with the basic idea of "holy", and often in relation to

For example, eunuchs (v. 1), those of unknown parentage or illegitimate birth (v. 2), and Ammonites and Moabites (vv. 3-6) are "excluded from civil leadership in Israel", while Edomites and Egyptians (of the third generation) are permitted to be among the congregation of Israel (civil leadership in Israel, vv. 7-8).

5 Bachmann (2013:293) notes that, "Some of them have the casuistic and others the apodictic formulations; some of them include theological justification supporting the prohibition or the command; some are very dry and others wholly expanded."

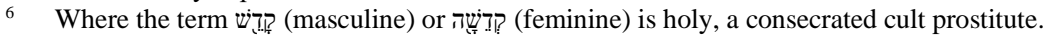




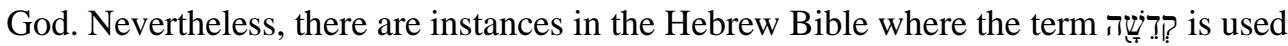
as a clear synonym for which refers to a woman who engages in illicit sex, either an adulteress or, plausibly, a prostitute (Gen 38; Hos 4:14) (Budin 2006:82).

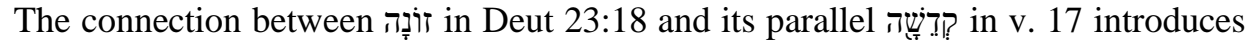
"cultic sex" in the prohibition of Deut 23:18, "with a categorical exclusion, binding it to the older law by the addition of the 'abomination' clause in v. $19 \mathrm{~b}$ and creating the impression of common subject matter" (Bird 2015:354; cf. Day 2004:3-6). In the Ancient Near East, sacred prostitution was understood as "the sale of a person's body for sexual purposes where some portion (if not all) of the money received for this transaction went to a deity" (Budin 2006:78). The gains from temple prostitution were used to pay for temple administration. While there is a connection between them in terms of the basic idea of "sacred", Frevel (2019:29) argues that, "to differentiate between an Israelite understanding of 'consecrated person' and a 'Canaanite' engagement of single 'consecrated persons' as cultic prostitutes is misleading".

In sacred prostitution sexual intercourse had a religious connotation and was performed to emulate the goddess or the god (usually in sacred marriage), to evoke fertility, fruitfulness and blessing (Frevel 2019:18). It appears that prostitution as a practice in the Ancient Near East was not regarded with moral disapproval and was considered normal. The most commonly observed feature of such primitive cultures was ritual prostitution (Budin 2006:79). Budin (2006:79) notes, "To the temple of the goddess of fertility (Inanna, Ishtar, and Astarte) were attached bordellos served by consecrated women who represented the goddess, the female principle of fertility."

Although evidence of such practices is indicated in classical literature such as Herodotus's Histories (1.199) and Strabo's Geography (6.2.6), it seems improbable that these women (or men) were cult prostitutes (Frevel 2019:18). Following this line of reasoning, Budin's comment becomes instructive,

There are no deities in either the Hebrew or Canaanite pantheons who are specifically sexual. Astarte, contrary to the later, classical opinions of her, was not a goddess of sex, nor was she sexual in her own persona. Likewise Asherah, here understood as her cognate Ugaritic Athirat, was pointedly married to the chief deity El. She was a sexual (as well as maternal) goddess, but her sexuality was of a distinctively regulated kind, a kind that stressed marriage and procreation. (Budin 2006:82-83)

In some studies, ideological dichotomies have been created between Canaanite religious and cultural traditions and those of Israel's religious ethos. Healey, for example, writes:

Israel's own religious ethos, at least what we know of it in the Bible, eschewed this kind of simple correlation between the divine and the natural ... There was a clear revulsion against Canaanite religious practices in the Yahwistic religion of early Israel. It can be seen in numerous injunctions, prescriptions, and stories that either directly or indirectly impugns the practices of the inhabitants of the land.

That the religion of Canaan exercised a stronghold over many Israelites is also clear ... But Israel's religious experience of God as it is articulated in the Hebrew Bible 
was not based in the phenomena of nature, nor in a vision of an eternal cycle of life. (Healey 1992:792-793)

In his description of the study of Albright, Yahweh and the Gods of Canaan, as an example of the obvious rivalry between Canaan and Israel, Frevel notes:

The Canaanites were driven by the obsession to evoke fertility were inferior and morally deficient. They engaged in sexual rites, especially in cultic prostitution ... 'sexual abuses in the service of religion' ... Thus the emphasis on fertility and sex became the standard theory for Canaanite 'Baalism', and the moral distinctiveness of the Israelites regarding sex issues became a part of their self-understanding. The Victorian moral values set the agenda. (Frevel 2019:17).

Interestingly, the culture and religion of ancient Israel were basically the same as those of other peoples of the Levant. Consequently, the contrast between "the Israelite" and "the Canaanite" lacks historical evidence in the Hebrew Bible and is thus diametrically positioned (Frevel 2019:17). Since there were no deities in the Hebrew Bible to whom sacred prostitution could be attached, one might argue that the term שק (masculine) and קִדָשָׁה (feminine) may have at one time referred to Canaanite cult functionaries who were later condemned by the Yahwistic cults of Israel (Budin 2006:83). It is, therefore, reasonable to simply treat Deut 23:18 as an independent prohibition in a series of stylistically similar prohibitions without assumptions of a fertility cult and "sacred prostitution" introduced by Deut 23:17 (Bird 2015:355).

\section{Metaphorical aspects: Between economic sustainability and religious observance}

Deuteronomy 23 focuses on two major thematic structures: "who is in the community and who is not?' (vv. 1-15), and 'what are some of our financial responsibilities to each of these?' (vv. 16-26)" (Bachmann 2013:295). The central focus of Deut 23:18 remains the financial and other consequences of belonging to the assembly of Yahweh's people. The key issue in the text is the prohibition of vows (gifts and donations) to the temple gained from immoral sources. Deuteronomy 23 does not give adequate information regarding the life, social status or working conditions of prostitutes (Bird 2015:357). ${ }^{7}$

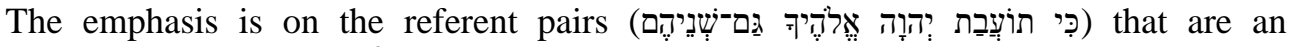
abomination to Yahweh. ${ }^{8}$ In this regard, the focal issue is the temple income and not prostitution itself (Bachmann 2013:293).

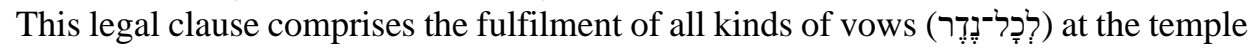

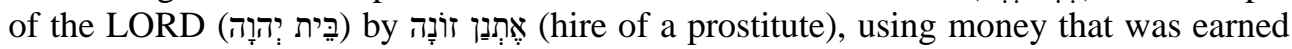
with prostitution, which is morally despicable. The parallel in Mic 1:7 indicates everything that is financed by prostitution money is considered as idols and should be burnt. Thus, in reference to Deut 23:18, it is appropriate to imagine the fulfilment of vows by means of such monies (Otto 2017:1791). With regard to vows, OT scholarship

Bird (2015:357) holds that, "Most biblical and extra-biblical references to prostitutes present them as independent operators."

8 תמוֹעִבַה (translated as abomination) "is a typically, but not exclusively, Dtr evaluation of objects, practices or persons unfit for YHWH, in a ritual as well as in an ethical sense" (Bachmann 2013:293). 
maintains that the making of vows was an essential component of ancient Israel's popular religious practice (Ginsberg 1945:161). ${ }^{9}$ This popularity is discussed in Tony Cartledge's insightful monograph, Vows in the Hebrew Bible and the Ancient Near East, where he remarks that,

The very presence of so many vow-like prayers within Israel's "hymnbook" is an indication of the popularity and meaningfulness of the practice. In my view, the prayers of the psalmists are not just those of a religious expert or professional hymnwriter. The laments, in particular, may express the needs and hopes of ordinary people, and utilize motivational tactics (such as vows) that are common to more popular forms of religion ... The presence of vows (always personal) in virtually every other society of the ancient Near East, and in form very similar to vows practiced in Israel, shows that vow-making was an important element of popular or "folk" religion throughout the ancient Near Eastern world of the first millennium. (Cartledge 1992:27-28)

In terms of the mechanisms of Israelite vows, scholarly discussions regard Deut 23:18 and 23:19 as constituting a legal unit with an autonomous regulation (Berlinerblau 1996:105). However, Steuernagel (1900:86) in Berlinerblau (1996:105) doubts the direct relation of vv. 17 and 18 to each other: "The two verses stem from different sources; whereas in v. 18 Israel is spoken of in the 3rd person, in v. 19 it is directly addressed. Verse 18, if taken literally, is superfluous and that is the reason why it is certainly not originally written as a continuation" (Steuernagel 1900:86).

A recognition and appreciation of prostitution as an economic engagement rather than a ritual activity, as well as the roles of gender and the responsibilities in fulfilling their religious obligations that calls for special regulation for women, have helped in the interpretation of the prohibition. From an economic perspective, it has been noted that women who generally had no autonomous means of income, may have been involved in prostitution in order to raise money for their sustenance and to pay their religious vows. Van der Toorn (1989:200-201; 1992:511) notes that the phenomenon of women engaging in prostitution to raise funds to fulfil their vows is well known. Although he denies the notion of widespread ritual prostitution in favour of a fertility cult (Van der Toorn 1989:203), in view of Deut 23:18, which emphasises some form of temple prostitution, Van der Toorn highlights the vow in the prohibition by citing the regulation in Num 30:1-16, that holds a woman's husband or father responsible for the fulfilment of any vows she might make. He explains that a woman may have had reasons for hiding her vows from her husband. In this regard he writes,

When the time of payment had come, she found herself in an awkward position. Unless she resorted to prostitution as a way to acquire the necessary means, she had to retract her promise, which was considered a very serious offense [(Deut]

9 Roland de Vaux (1965:465) remarks that: "A vow (neder) is a promise to give or to consecrate to God a person or thing, e.g. a tithe (Gen 28:20-22), a sacrifice (2 Sam 15:8), plunder taken in war (Num 21:2), a person (Judg 11:30-31; 1 Sam 1:11)." 
23:22[21]; Eccl 5:3). In certain sections of the population, prostitution under these circumstances may have seemed preferable, so long as the revenues were set apart for the Temple treasury. (Van der Toorn 1989:200)

However, his conclusion moves from conjecture to assertion:

We may conclude that the phenomenon of women - and, occasionally, men prostituting themselves in order to obtain the money to fulfil their vows was well known and to some extent accepted in broad layers of the Israelite society. Until the Deuteronomic reform, it seems to have been tolerated by the official religion, which preferred the resulting votive gifts over an ethical rigorism. (Van der Toorn 1989:201)

Whilst this conclusion makes the text relatively understandable, the interpretation raises some critical concerns. Granted that prostitution was not a ritual act but an economic activity with some religious obligations attached, what then was the connection to the male addressee and why was such income from a desperate woman classed as the "hire of a harlot" (את מְנַן זוֹנָה)? Should a vow lead to economic bondage of

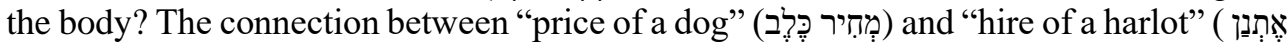

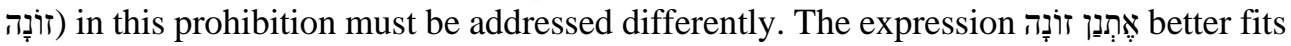
a professional prostitute than a married woman who engages in prostitution as a single desperate act, as a common resort for women in economic straits (Bird 2015:356).

The reference to זוֹנָה in Deut 23:18 is not logically connected to the wages of a prostitute, but a follow-up of the reference to the temple and thus governs both (hire of a harlot) and מִזִיר כֶּרֶב (price of a dog). The text refers to two sources of revenue

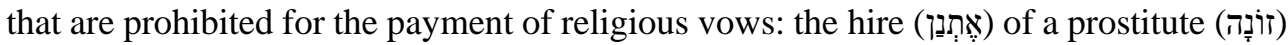

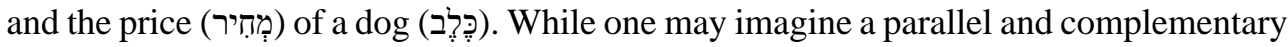
role of female or male prostitutes in the text, ${ }^{10}$ metaphorical use of dogs and prostitutes as ultimate symbols of shame and disgrace, is most probable in Deut 23:18. Since the only reference to a professional prostitute in the Deuteronomistic History is הֶּנֶּן זוֹנָּה the regulation against the use of her wages (hire) for the fulfilment of vows in the temple, it makes sense to establish the reason behind the prohibition. Commenting on the two

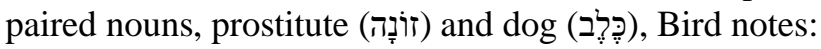

What we have here is two symbols of contempt or low regard, the whore and the hound-marginal figures in the society, unclean, without honour-and with no

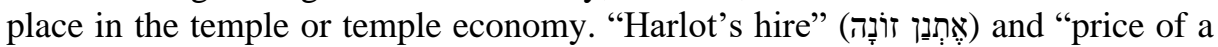
dog" (מְחזיר כֶּלֶב should be understood, I believe, as fixed or formulaic expressions, clichés or "commonplaces" that we have failed to recognise. (Bird 2015:360)

The prohibition points to a priestly concern regarding the payment of vows to the temple with money acquired immorally (De Vaux 1965:466; Carmichael 1974:190). Berlinerblau (1996:105), quoting Buis and Leclercq (1963:157), states: "The law does

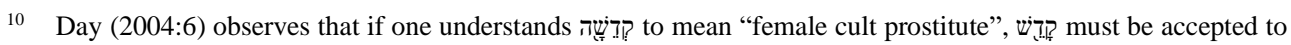

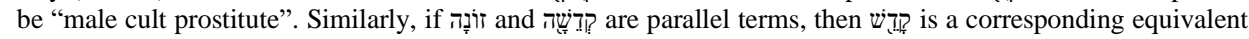
to כִֶֶּ. 
not only prohibit Israelites from prostituting themselves (v. 18) but also from using sacred prostitutes, even foreign ones; the most likely sense of 'to bring the salary of a prostitute' (v. 19) is, in effect: 'to hire oneself a prostitute'. The ritual Yahwist rejects this custom." Obviously, the target of Deut 23:18 seems to be the fulfilment of vows through "contemptible" or otherwise "filthy" money rather than ritual or cultic

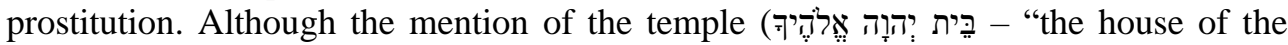
LORD your God") may suggest that such money is ritually unclean, there is nothing in the text that indicates ritual purity. What one can infer from the text, is the revulsion that is associated with the depreciating and unsupportive character or insignificant amount offered as payment of vows. From the perspective of Deut 23:18, the "hire of a harlot"

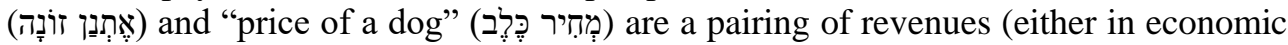
or spiritual value) that are objectionable due to their connection with obvious symbols of shame and disgust (Bird 2015:361-362).

The connection of a harlot with a dog in the text is simply to demonstrate the pair's strong sexual desires, their lack of self-esteem and moral depravity. Consequently, in upholding the dignity, worth and reverence of vows and sacrifices as sacred things, the contemptibility and vileness of these characters are primarily considered in this

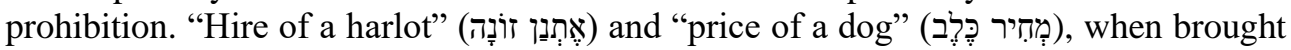
as offerings or sacrifices in fulfilment of vows to Yahweh, violate moral laws, demonstrate contempt for the sacrifices of ritual or ceremonial laws (cf. Lev 19), and may even been seen as a token of loyalty to idolatry, and are nothing but abominable to God (תוֹעָבָבת), who has no pleasure in anything unholy, immoral or disreputable.

\section{Concluding remarks}

This article examined Deut 23:18 within the parameters of lexical and literal aspects

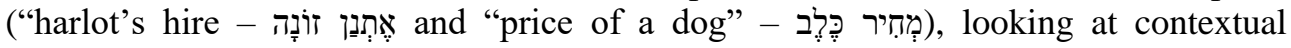
perspectives (cultic and temple prostitution) and metaphorical aspects (economic

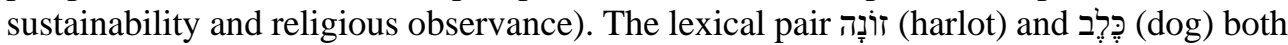
have literal and metaphorical meanings in different contexts. From the contextual analysis, historical evidence regarding cultic or temple prostitution in ancient Israel or elsewhere in the Ancient Near East is inconclusive and unconvincing, although "cultic" and "secular" prostitution can be imagined.

In the immediate context, one can observe that God hates both secular and cultic prostitution and prohibits Israelite's sons and daughters from involvement. The text does not, however, show that God hates the prostitutes themselves. Thus, prostitutes are not clearly referred to in Deut 23:18. Deut 23:18 falls within a context of regulations regarding economic dealings: interest on loans and payment of religious vows. The text itself is concerned more with financial ethics than cultic or sexual activities - local or foreign. While God does not hate prostitutes (as the text indicates), the practice of the hire of a prostitute and wages of a dog for the fulfilment of temple vows (probably vows of gratitude for God's provision, and other religious forms of vows) is an abomination decried by God.

It is clear that Deut 23:18 forbids the practice of institutionalised cultic prostitution

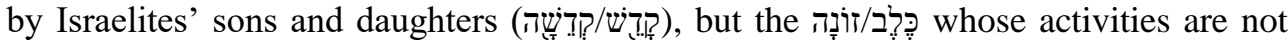
specifically forbidden, are clearly charged not to make use of money obtained through prostitution to redeem their vows. The "hire of a harlot" (צֶתנֶנן זוֹנָה) and the "price of a 
dog" (מְחזיר כֶּלֶב are a clear referent pair in the prohibition of Deut 23:18. Both elements of this pair are metaphorical symbols of shame and disgrace. The represents the primary female example of the social outcast, defined by sexual activity normally prohibited. Desired and tolerated, but stigmatised and ostracised, the biblical prostitute is frequently deployed as a symbol of generalised sexual immorality and thus of

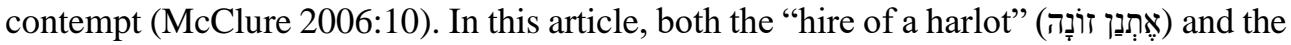

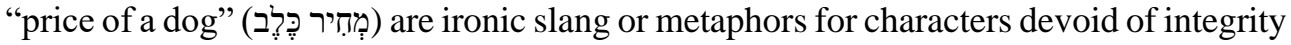
and for something of very low value, too insignificant for fulfilling vows.

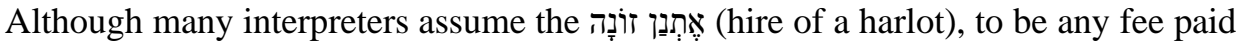
to a prostitute for her service, the אֶתֶֶ, of Deut 23:18 does not specifically imply definite, obvious payments of revenue. Since אֶתְֶֶ is almost always typically employed metaphorically (Isa 23:17-18; Ezek 16:31, 34, 41; Hos 9:11; Mic 1:7), in keeping with the figurative usage, it is most probable that אֶתֵֶ symbolises wealth that is worthless from beneficiaries who were not faithful to Yahweh. If one accepts this understanding of Deut 23:18, namely that payment of religious vows requires integrity and value, what can one say about proceeds of corruption, stolen funds from public treasury, ritual money etc., which are used for offerings and thanksgiving in various religious communities in the world today (especially in Africa)? Can these be regarded as contemptible, contaminated or corrupt and unethical and thus be rejected by religious communities? The prohibition of Deut 23:18 no doubt presents some ethical demands for contemporary religious communities' reflection.

\section{BIBLIOGRAPHY}

Albright, WF. 1965. Yahweh and the Gods of Canaan: A historical analysis of two contrasting faiths. Jordan Lectures in Comparative Religion 7. London: Athlone Press.

Allen, LC. 1973. Micah's social concern, Vox Evangelica 8:22-32.

Andersen, FI and Freedman, DN. 2000. Micah: A new translation with introduction and commentary AB 24E. New York: Doubleday.

Bachmann, MLG. 2013. Women at work in the Deuteronomistic history. International voices in Biblical studies 4. Atlanta: Society of Biblical Literature.

Bergant, D. 1994. 'My beloved is mine and I am his' (Song 2:16): The Song of Songs and honor and shame, Semenia 68:23-40.

Berlinerblau, J. 1996. The vow and the 'popular religious groups' of Ancient Israel: A philological and sociological inquiry, Journal for the Study of the Old Testament Sup. Series 210. Sheffield: Sheffield Academic Press.

Bird, PA. 2006. Prostitution in the social world and the religious rhetoric of Ancient Israel. In Christopher A Faraone and Laura K McClure (eds), Prostitutes and courtesans in the ancient world. Madison: University of Wisconsin Press, 40-58.

Bird, PA. 2015. Of whores and hounds: A new interpretation of the subject of Deuteronomy 23:19, Vetus Testamentum 65:352-364.

Brayford, SA. 1999. To shame or not to shame: Sexuality in the Mediterranean Diaspora, Semeia 87:163-176. 
Brown, F, Driver, SR and Briggs, CA (eds). 1997. The new Brown-Driver-BriggsGesenius Hebrew and English lexicon of the Old Testament. Peabody: Hendrickson Publishers.

Budin, SI. 2006. Sacred prostitution in the first person. In Christopher A Faraone and

Laura K McClure (eds), Prostitutes and courtesans in the ancient world. Madison: University of Wisconsin Press, 77-92.

Buis, P and Leclercq, J. 1963. Le Deuteronome, Sources bibliques. Paris: J Gabalda. Carmichael, C. 1974. The laws of Deuteronomy. Ithaca, NY: Cornell University Press. Cartledge, T. 1992. Vows in the Hebrew Bible and the Ancient Near East, Journal for the Study of the Old Testament Sup. Series 147. Sheffield: JSOT Press.

Day, J. 2004. Does the Old Testament refer to sacred prostitution and did it actually exist in Ancient Israel? In C McCarthy and JF Healey (eds), Biblical and Near Eastern essays: Studies in honour of Kevin J. Cathcart, JSOT Sup. 375, 2-21.

Dempster, SG. 2017. Micah. In The two horizons Old Testament commentary. Grand Rapids, Michigan: William B. Eerdmans Publishing Company.

Dietrich, J. 2012. Um der ehre willen: Formen der ehre im alten Israel, Bibel und Kirche 1:16-20. Online: https://www.bibelwerk.de/sixcms/media.php/169/biki [Accessed: 12/07/2019].

Frevel, C. 2019. Semper aliquid haeret! The accusation of fornication and of sexualized cults as a means of demarcation in the Hebrew Bible. In A Cuffel, A Echevarria and GT Halkias (eds), Religious boundaries for sex, gender, and corporeality. London: Routledge, 11-32.

Frymer-Kensky, T. 1992. Deuteronomy. In Carol A Newsom and Sharon Ringe (eds), The women's Bible commentary. Louisville: Westminster John Knox Press.

Ginsberg, HL. 1945. Psalms and inscriptions of petition and acknowledgement. In Louis Ginzberg jubilee volume: On the occasion of his seventieth birthday. New York: The American Academy for Jewish Research, 159-171.

Healey, JD. 1992. Fertility cults. In Daniel N Freedman (ed.), Anchor Bible dictionary. New York: Doubleday, 791-793.

Koehler, L and Baumgartner, W. 2000. The concise Hebrew and Aramaic lexicon of the Old Testament. Leiden; New York: Brill.

Matthew, VH. 1998. Honor and shame in gender-related legal situations in the Hebrew Bible. In Victor H Matthews, Bernard M Levinson and Tikva Frymer-Kensky (eds), Gender and law in the Hebrew Bible and the Ancient Near East. Journal for the study of the Old Testament Sup. Series 262. Sheffield: Sheffield Academic Press, 97-112.

Mays, JL. 1976. Micah: A commentary. London: SCM Press Ltd.

McClure, LK. 2006. Introduction. In Christopher A Faraone and Laura K McClure (eds),

Prostitutes and courtesans in the ancient world. Madison: University of Wisconsin Press, 3-20.

Nogalski, JD. 2011. The book of the twelve: Micah-Malachi. Macon, Georgia: Smyth \& Helwys Publishing, Inc.

Oswalt, JN. 1980. כֶֶּב. In RL Harris and GL Archer Jr (eds), TWOT. Chicago: Moody Press, 981.

Otto, E. 2017. Deuteronomium 23:16 - 34:12. In Herders Theologischer Kommentar zum Alten Testament. Freiburg: Herder, 1719-2302. 
Simkins, RA. 1994. Return to Yahweh: Honor and shame in Joel, Semenia 68:41-54.

Simkins, RA. 2005. Honor and shame in Genesis 34 and 1 Samuel 25. In Mark Roncace and Patrick Gray (eds), Teaching the Bible. Leiden: Brill, 104-106.

Stansell, G. 1994. Honor and shame in the David narratives, Semenia 28:55-79.

Stone, KA. 1995. Gender and homosexuality in Judges 19: Subject-honor, object-shame, Journal for the Study of the Old Testament 61:87-107.

Steuernagel, C. 1900. Ubersetzung und erkldrung der bucher Deuteronomium und Josua und allgemeine einleitung in den hexateuch HKAT. Gottingen: Vandenhoeck \& Ruprecht.

Van der Toorn, K. 1989. Female prostitution in payment of vows in Ancient Israel, Journal for Biblical Literature 108:193-205.

Van der Toorn, K. 1992. Cultic prostitution. In Anchor Bible dictionary 5. New York: Doubleday, 510-513.

Vaux, R. 1965. Ancient Israel: Religious institutions. New York: McGraw-Hill.

Von Rad, G. 1962. Old Testament Theology. London: Oliver \& Boyd.

Waltke, BK. 2007. A commentary on Micah. Grand Rapids: Eerdmans.

Wood, LJ. 1980. זנזָה In RL Harris and GL Archer Jr (eds), TWOT. Chicago: Moody Press, 563. 